\title{
EFFECT OF FLOODING MANAGEMENT ON CARBON CONTENT OF SOIL AND PLANT AFTER CESSATION OF PADDY RICE CULTIVATION
}

\author{
SHIMODA, S. $^{1}{ }^{*}-$ SAKURAI, Y. ${ }^{2}$ \\ ${ }^{I}$ NARO Western Region Agricultural Research Center (NARO/WARC) \\ Nishifukatu 6-12-1, Fukuyama, Hiroshima, Japan \\ (phone: +81 84-923-4100; fax: +81 84-924-7893) \\ ${ }^{2}$ Faculty of Agriculture, Ehime University \\ Tarumi 3-5, Matsuyama, Ehime, Japan \\ (phone: +89-946-9893; fax: +89-946-9963) \\ *Corresponding author \\ e-mail: sss@affrc.go.jp \\ (Received 29 $9^{\text {th }}$ September 2011; accepted $5^{\text {th }}$ September 2013)
}

\begin{abstract}
We measured soil carbon (C) and its stable isotopic composition in paddy fields that had received different fallow treatments for 6 years to investigate how management practices influenced the response of soil $\mathrm{C}$. The experiment compared 4 fallow treatments in neighboring fields: mowing twice a year and no tillage (MN), mowing twice a year and puddling once a year (MP), and flooding to 5 or 15 $\mathrm{cm}$ and puddling (WP5, WP15) to prevent succession to wasteland and thus permit future cultivation. MN had the potential to increase soil C more than MP5 through larger root and shoot buildup. However, the total soil $\mathrm{C}$ content to a depth of $30 \mathrm{~cm}$ was significantly higher in WP5 (13.7 $\left.\mathrm{Mg} \mathrm{C} \mathrm{ha}^{-1}\right)$ than in MN (11.8 $\left.\mathrm{Mg} \mathrm{C} \mathrm{ha}^{-1}\right)$. The dry-fallow management increased plant growth while reducing soil $\mathrm{C}$. The large root dry weight in MN and MP could have increased soil $\mathrm{C}$ through high root turnover, whereas land use change from flooding to dry-land masked the abundant $\mathrm{C}$ input. After cultivation stops, flooding plays a significant role in preventing root growth and $\mathrm{C}$ sequestration in fallow paddy fields.
\end{abstract}

Keywords: agricultural abandonment, carbon sequestration, fallow, irrigation, LULUC, stable carbon isotope, weed control

\section{Introduction}

Rice (Oryza sativa L. Gramineae) has been grown in the paddy fields of monsoon Asia for thousands of years. In Japan, rice paddies constitute the most common farmlands, accounting for 54\% of the total agricultural land in 2008 (MAFF, 2009), and are thus the main component of agricultural landscapes. The number of abandoned and fallow paddy fields has recently increased because of industrialization and the aging of farmers and such paddy fields now account for nearly $10 \%$ of the total cultivated land area in Japan. Rice paddies in monsoonal Asia play an important role in the global $\mathrm{C}$ budget. Past and current land use and land use changes (LULUC) contribute to cause large emissions of carbon dioxide $\left(\mathrm{CO}_{2}\right)$. Uncertainties in the quantitative understanding of the impact of LULUC on the $\mathrm{C}$ cycle affect the formulation of emission mitigation strategies (Strassmann et al., 2008).

Fallow management practices can alter species composition and cycling of ecosystem nutrients and $\mathrm{C}$, and soil $\mathrm{C}$ pools can be changed. Flooding and puddling management practices affect soil $\mathrm{C}$ accumulation through shoot and root $\mathrm{C}$ input. Previous studies have revealed that flooding suppresses paddy weeds and controls their 
germination and dry weight (e.g. Kent et al., 2001; Yamada et al., 2007). Annual puddling restricts the dominance of rhizomatous perennials, which alters the quantity and quality of shoots and roots. Fallow management practices, such as flooding, also affect soil organic $\mathrm{C}$ decomposition. During flooding, $\mathrm{CO}_{2}$ production in the soil is severely restricted because of the anaerobic conditions. Owing to their unique biochemical processes and the physical mechanisms associated with ponding, paddy soils have greater potential for $\mathrm{C}$ sequestration than do upland cultivated soils (Pan et al., 2004; Nishimura et al., 2008). Although there is a general lack of knowledge of the impacts on soil C after cultivation ends, soil physical properties (Ohta et al., 1996) and the soil properties and vegetation in Japan (Anzai and Matsumoto, 1988) and China (Zhang et al., 2007) have been studied.

Weed biomass production act as conduits transporting $\mathrm{C}$ into belowground $\mathrm{C}$ pools in fallow and abandoned fields. Perennial weeds have thicker and denser root systems than annuals to maximize below-ground resource acquisition (Roumet et al., 2006), and upland weeds are generally able to survive drought periods because of these extended root systems, which are difficult to completely remove. The overall amount of weed roots increases the longer a field has been abandoned, which discourages re-cultivation of fallowed paddy fields (Shimoda, 2008). To avoid the succession from annual weeds (which are easier to control) to perennials (which are more difficult to control), water flooding and tillage are fallow management schemes that help to eliminate weeds, particularly perennial weeds (Bhagat et al., 1996; Yamada et al., 2007).

Although some studies have reported that flooding management programs should be launched to preserve paddy fields in a wet condition to conserve rare arable weeds in abandoned paddy fields (Shimoda and Nakamoto, 2003; Yamada et al., 2007), little information has emerged on fallow management practices that effect the plant rootshoot buildup and restoration of soil $\mathrm{C}$ after rice paddy cultivation has ceased. The purpose of this study was to evaluate the $\mathrm{C}$ storage management strategies through different plant structure in a fallow paddy field. For this purpose, 2 dry treatments and 2 flooded treatments were conducted in contiguous fields for 6 years. We then collected a set of soil and plant samples from each field to examine how fallow management practices affected $\mathrm{C}$ stocks.

\section{Materials and methods}

\section{Study site}

Our study site is on the island of Shikoku in the southwestern part of Japan. The expansion of abandoned terrace paddy fields in hilly and mountainous areas of this district has caused the deterioration of rural landscapes. Terrace paddy fields can be irrigated with abundant natural water resources from springs and rain in most parts of this area, so using flooding to manage abandoned terrace paddy fields in this area is both reasonable and practical.

The study site was located in Toon, Ehime, Japan $\left(33^{\circ} 45^{\prime} \mathrm{N}, 132^{\circ} 55^{\prime} \mathrm{E}, 390-\right.$ $400 \mathrm{~m}$ asl), and comprised 4 fallow paddy fields an active rice field. The mean annual air temperature and mean annual precipitation over the period $1975-2005$ were $16.2{ }^{\circ} \mathrm{C}$ and $1319 \mathrm{~mm}$ (Japan Meteorological Agency). The soil is a Gleyic, Humic Alisol (FAO/UNESCO), and the soil clay content was $22 \%$ in the top $30 \mathrm{~cm}$. The underlying material is an impermeable mudstone. Rice is grown mostly in valley heads. No intensive land improvement and development of water control systems are practiced 
because of the low economic efficiency of such small paddy terraces; hence, paddy fields are irregular in shape and drainage remains good in all seasons. Each field is very small, ranging from 160 to $300 \mathrm{~m}^{2}$ and averaging $240 \mathrm{~m}^{2}$. The soil type and land-use history were same for all of the fields. Based on oral history, agriculture was established in this area more than 500 years ago, and these fields had been used for paddy rice cultivation by conventional methods before they were abandoned. The same agricultural practices (e.g. tillage, irrigation, and fertilization with $\mathrm{N}, \mathrm{P}$, and $\mathrm{K}$ ) were historically used in each of the study fields. Because the soil type and cultivation practices for the study fields were the same before the fallow management treatments began, the pedogenic environment and initial soil $\mathrm{C}$ storage for the fields were considered to be similar, and the soil in the adjacent cultivated rice field was considered a control.

\section{Fallow and rice management practices}

The experiment compared 4 different fallow treatments in neighboring fields: mowing twice a year and no tillage (NT); mowing, plowing, and puddling, and no flooding (NF); and mowing, plowing, and puddling, and flooding to either 5 or $15 \mathrm{~cm}$ (F5, F15). A rice cropping paddy field (Rice) a near the area was used as a reference field. The fallow management practices started in 2002, and the treatment schedule is depicted in Figure 1.

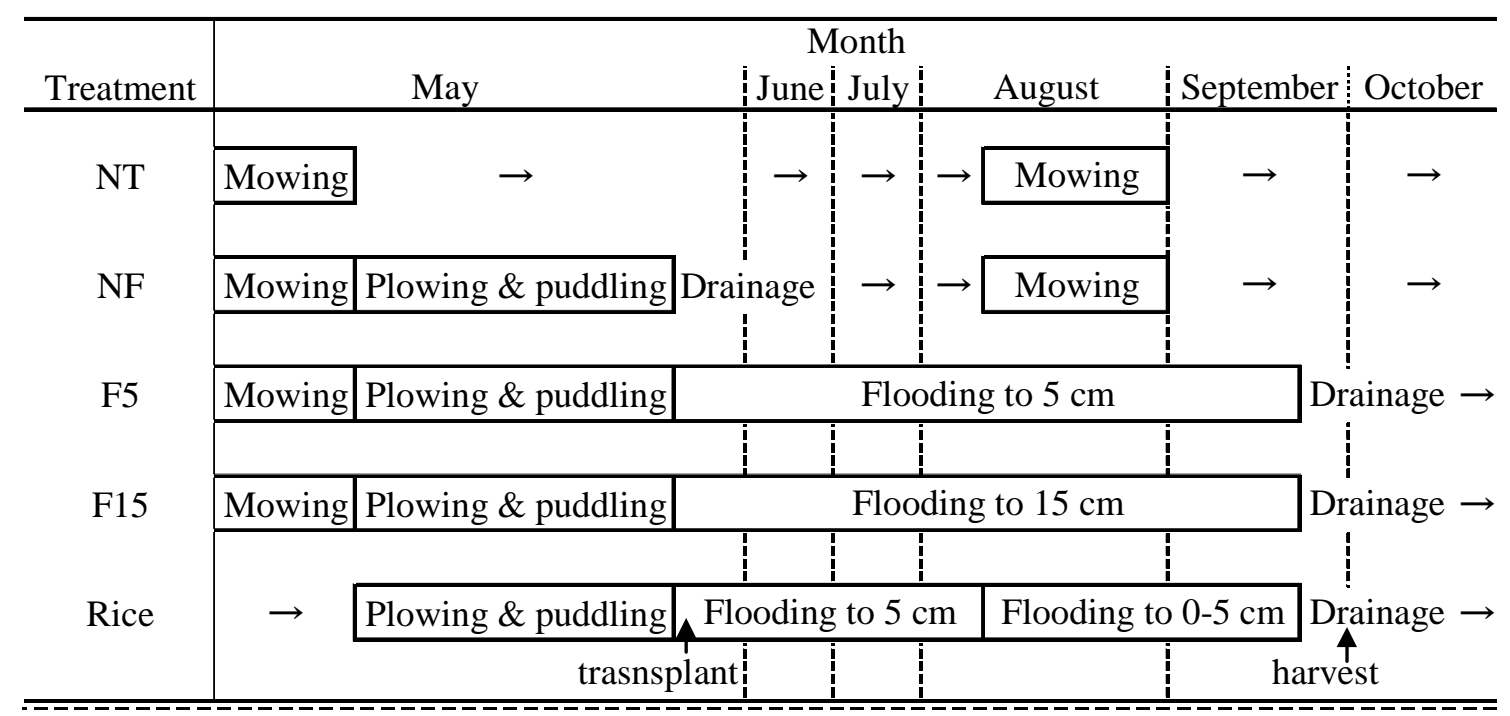

Figure 1. Schedule of operations during the growing season in each of the 5 treatments

Based on oral history, all rice straw had been harvested was incorporated into soil in the spring except for some year. With the exception of NT, the fields were plowed in mid-May each year. A few days before the rice field was planted, the NF, F5, F15, and rice fields were plowed to about 10 to $15 \mathrm{~cm}$ deep, flooded, puddled, and leveled ("surface soil puddling"), then all plant residues were then plowed into the soil. In the NF treatment the field was drained after leveling. Water was supplied to the F5 and F15 fields from an irrigation canal via bamboo pipes during the rice cultivation period. Water depth was controlled with wave plates around the fields. The outline of the water management of the rice field during the rice cultivation period was based on Japanese 
conventional practices of continuous flood irrigation before summer, drainage and subsequent intermittent flood irrigations in summer, and final drainage about 20 days before the rice harvest in autumn. In October, all fields were drained and the rice was harvested. All fallow fields were mown with a shoulder-held mower once a year in midMay, and NT and NF were mown again in late August.

\section{Soil, root, and plant samples}

In early September 2008, soil and root samples were collected from the 4 fallow paddy fields and the rice paddy parcel. Six or seven sampling plots were established at 5-m intervals in the east-west direction in each field. Before the soil was sampled, plants were cut at the level of the ground surface and plant litter was removed. Samples were taken from layers at depths of 0-10, 10-20, and 20-30 cm with a liner sampler (55$\mathrm{mm}$ diameter). Air-dried samples were passed through a 2-mm sieve and roots were removed by hand. The soil and root samples were then oven-dried to constant mass $\left(40^{\circ} \mathrm{C}, 7\right.$ days). Soil bulk density was calculated by dividing the oven-dry mass of the $<2$-mm fraction by the volume of the core segment. After the roots had been oven-dried, we shook them to remove much of the attached soil. Root samples were hand-sorted into fine (diameter $<2.0 \mathrm{~mm}$ ) size classes. To estimate the shoot dry weight of each weed species, we collected aboveground biomass from 3 representative quadrats $(0.50$ $\mathrm{m} \times 0.50 \mathrm{~m}$ ) in each field. After the shoots had been oven dried at $80^{\circ} \mathrm{C}$ for $48 \mathrm{~h}$, the shoot dry weight was determined. $\mathrm{pH}$ was measured by mixing each soil sample in deionized water $(1: 2.5 \mathrm{w} / \mathrm{v})$. Volumetric soil moisture content was measured with a water content electrical conductivity temperature sensor (WET-2, Delta-T, Cambridge, UK). Plant shoots were divided into 5 dominant species (Setaria viridis, Digitaria ciliaris, Echinochloa oryzicola, Artemisia indica, and Monochoria vaginalis) and rice (Oryza sativa) to measure the dry weight and stable isotopic composition of $\mathrm{C}\left(\delta^{13} \mathrm{C}\right)$.

\section{Soil carbon content and stable isotopic composition}

Many previous studies have used the $\delta^{13} \mathrm{C}$ as a natural tracer when $\mathrm{C}_{3}$-crop-derived soil $\mathrm{C}$ is replaced by new $\mathrm{C}_{4}$-weed-derived soil $\mathrm{C}$ (Shimoda, 2008). Therefore, we also measured $\delta^{13} \mathrm{C}$ of soil to evaluate the contribution of $\mathrm{C}_{4}$ weeds to soil $\mathrm{C}$ storage. $\delta^{13} \mathrm{C}$ is defined as

$$
\delta^{13} C(\%)=\left\{\frac{\left({ }^{13} C /{ }^{12} C\right)_{s a}}{\left({ }^{13} C /{ }^{12} C\right)_{s t}}-1\right\} \times 1000
$$

where the subscripts " $s a$ " and "st" denote the sample and the Vienna Pee Dee Belemnite standard, respectively. The fraction of $\mathrm{C}_{4}$-derived $\mathrm{C}$ on the soil $\mathrm{C}$ sample $\left(f_{\mathrm{C} 4}\right)$ was calculated with following equation (e.g., Shimoda et al., 2009):

$$
f_{C 4}=\frac{\delta^{13} C_{S}-\delta^{13} C_{3}}{\delta^{13} C_{4}-\delta^{13} C_{3}}
$$

where $\delta^{13} C_{\mathrm{S}}$ is the measured $\mathrm{C}$ isotope ratio of the soil, and $\delta^{13} C_{3}$ and $\delta^{13} C_{4}$ are the measured $\mathrm{C}$ isotope ratios of plant organic matter for $\mathrm{C}_{3}$ and $\mathrm{C}_{4}$ species, respectively. 
For each field, the weed-derived $\delta^{13} C$ value $\left(\delta^{13} C\right.$ value of total dry weight $)$ can be calculated by the following mass-balance equation (Mo et al., 2004):

$$
\delta^{13} \mathrm{C}_{\text {weed }}=\sum_{\mathrm{i}=1}^{\mathrm{n}}\left(\delta^{13} \mathrm{C}_{\text {weed (i) }} \times \alpha_{\text {weed (i) }}\right)
$$

where $\delta^{13} C_{\text {weed(i) }}$ is the carbon isotope ratio of weed species $(i), \alpha_{\text {weed (i) }}$ is the percent dry weight of weed species $i$ to total dry weight, and $n$ is the number of weed species in the plot. The plant $\delta^{13} C$ value $\left(\delta^{13} C\right.$ value of total dry weight) of the field can be similarly calculated as the sum of $\delta^{13} C$ value of each species multiplied by its percent dry weight. We calculated the $f_{\mathrm{C}_{4}}$ values at a $\mathrm{C}_{4}$-dominated fallow field. Because the same rice cultivar and management practices were used for a long time in the study area, the initial $\delta^{13} C$ value of soils in the fields were assumed to be the same. Therefore, $f_{\mathrm{C}_{4}}$ is nearly equal to the weed-derived contribution of $\mathrm{C}$ to soil when the soil $\delta^{13} C$ value in Rice field considered as a control.

Dried soil and plant samples were oven-dried at $80{ }^{\circ} \mathrm{C}$ for at least 48 hours and then ground into fine powder in a Multi-beads shocker (Yasui Kikai, Osaka, Japan) for the analysis of $\mathrm{C}$ concentration and $\delta^{13} \mathrm{C}$. Approximately $20 \mathrm{mg}$ of soil or $2 \mathrm{mg}$ of plant samples was weighed in a tin cup and combusted in an elemental analyzer (Flash EA 1112, ThermoFinnigan Co., Bremen, Germany) coupled to an isotope ratio mass spectrometer (Delta plus Advantage, ThermoFinnigan) by a Conflo III interface. The soil $\mathrm{N}$ concentration was also determined with the elemental analyzer. The plant $-\delta^{13} \mathrm{C}$ values were derived from measurements of well-mixed shoot for each species. The precision of the $\mathrm{C}$ isotope measurements was estimated to be within $0.13 \%$. Soil $\mathrm{C}$ and $\mathrm{N}$ contents were calculated by multiplying the $\mathrm{C}$ and $\mathrm{N}$ concentrations, the bulk density, and the depth of the soil layer.

\section{Statistical analyses}

Tukey's honestly significant difference test (significance level set at $P<0.05$ ) was used to test differences in means and to evaluate the effects of each management treatment on soil $\mathrm{C}$ and $\mathrm{N}$ contents, $\delta^{13} \mathrm{C}$, and root dry weight. Statistical analyses were conducted with $\mathrm{R}$ statistical software ( $\mathrm{R}$ version 2.4.1, R Foundation for Statistical Computing, Vienna, Austria).

\section{Results}

The flooded fields were dominated by paddy weeds (Table 1): Echinochloa oryzicola (Gramineae) in F5 and Monochoria vaginalis (Pontederiaceae) in F15. Flood tolerance is extremely well developed in these species (Bhagat et al. 1999; Kennedy et al. 1980), which can germinate under anaerobic conditions and grow at high speed even in deeply flooded fields. NT was dominated by the upland weeds Digitaria ciliaris, Setaria viridis (Gramineae), and Artemisia indica (Compositae), and NF by D. ciliaris. A perennial weed (A. indica) dominated in NT. The lowest shoot dry weight was $2.5 \mathrm{Mg} \mathrm{ha}^{-1}$ in F15. The shoot dry weights and species compositions were similar to those in a previous study in these fields (Yano and Sakurai, 2009). 
The root dry weight in the top $10 \mathrm{~cm}$ was significantly larger in NT (5.3 $\left.\mathrm{Mg} \mathrm{ha}^{-1}\right)$ than in the F5, F15, and rice fields (Fig. 2). F15 had the lowest root dry weight $(0.8 \mathrm{Mg}$ $\mathrm{ha}^{-1}$ in F15). In NF, F5, F15, and the rice field, root dry weight decreased exponentially with depth, with less than $20 \%$ in the top $10 \mathrm{~cm}$. In NT, $38 \%$ of the total root dry weight was distributed below $10 \mathrm{~cm}$. The coarse root weight in NT was more than one-third of the total (fine + coarse) root weight in the top $10 \mathrm{~cm}$ (Fig. 2). The total root weight in each of the flooded fallow fields was entirely composed of fine roots at all depths.

Table 1. Shoot dry weight $\left(M g h a^{-1}\right)$ and $\delta^{13} \mathrm{C}$ values (\%o) in each species

\begin{tabular}{l|c|c|c|c|c|c|c|c}
\hline \multicolumn{1}{c}{ Species } & \multirow{2}{*}{ Type } & \multirow{2}{*}{$\begin{array}{c}\text { Life } \\
\text { form }\end{array}$} & \multirow{2}{*}{$\boldsymbol{\delta}^{\mathbf{1 3}} \mathbf{C}$} & \multicolumn{5}{c}{ Treatment } \\
\cline { 5 - 8 } & & & & $\mathbf{N T}$ & $\mathbf{N F}$ & $\mathbf{F 5}$ & $\mathbf{F 1 5}$ & Rice \\
\hline Setaria viridis & $\mathrm{C}_{4}$ & annual & -13.5 & 2.2 & 0.1 & 0.1 & & \\
Digitaria ciliaris & $\mathrm{C}_{4}$ & annual & -13.4 & 0.8 & 3.1 & 0.0 & \\
Echinochloa oryzicola & $\mathrm{C}_{4}$ & annual & -13.4 & & & 6.1 & & \\
Artemisia indica & $\mathrm{C}_{3}$ & perennial & -29.8 & 2.8 & 0.0 & & & \\
Monochoria vaginalis & $\mathrm{C}_{3}$ & annual & -28.8 & & & & 2.5 & \\
Oryza sativa & $\mathrm{C}_{3}$ & annual & -28.5 & & & & & 5.8 \\
Other & & & & 1.1 & 0.1 & 0.0 & 0.0 & 0.0 \\
Shoot dry weight & & & & 6.9 & 3.3 & 6.2 & 2.5 & 5.8 \\
\hline
\end{tabular}

We did not include the weights of spikelets in the rice field.

Soil bulk densities at each depth were not significantly different among the fields (Table 2). Soil $\mathrm{pH}$ was approximately 7.0 in all fields at all depths except the top $10 \mathrm{~cm}$ of NT, was not altered by land use change from paddy fields into fallow fields. Soil water content values obviously reflected differences in water management among the fields.

Table 2. Soil $\mathrm{pH}$, moisture (\%) and bulk densities $\left(\mathrm{Mg} \mathrm{m}^{-3}\right)$ at each depth ( \pm standard error)

\begin{tabular}{|c|c|c|c|c|c|c|c|c|c|c|}
\hline Depth(cm) & Treatment & \multicolumn{3}{|c|}{ Bulk density } & \multicolumn{3}{|c|}{ pH } & \multicolumn{3}{|c|}{ Soil moisture } \\
\hline \multirow[t]{5}{*}{$0-10 \mathrm{~cm}$} & NT & 0.83 & \pm 0.10 & $\mathrm{a}$ & 6.4 & \pm 0.0 & $\mathrm{~b}$ & 25.7 & \pm 1.3 & $\mathrm{c}$ \\
\hline & $\mathrm{NF}$ & 0.86 & \pm 0.04 & $\mathrm{a}$ & 6.9 & \pm 0.2 & $\mathrm{a}$ & 16.5 & \pm 1.1 & $\mathrm{C}$ \\
\hline & F5 & 0.89 & \pm 0.04 & $\mathrm{a}$ & 6.9 & \pm 0.2 & $\mathrm{a}$ & 68.5 & \pm 0.7 & $\mathrm{a}$ \\
\hline & F15 & 0.87 & \pm 0.03 & $\mathrm{a}$ & 7.1 & \pm 0.1 & $\mathrm{a}$ & 77.0 & \pm 1.9 & $\mathrm{a}$ \\
\hline & Rice & 0.91 & \pm 0.02 & $\mathrm{a}$ & 6.7 & \pm 0.3 & $\mathrm{a}$ & 48.5 & \pm 2.3 & $\mathrm{~b}$ \\
\hline \multirow[t]{5}{*}{$10-20 \mathrm{~cm}$} & NT & 1.00 & \pm 0.02 & $\mathrm{a}$ & 6.8 & \pm 0.2 & $\mathrm{a}$ & - & - & \\
\hline & $\mathrm{NF}$ & 0.95 & \pm 0.06 & $\mathrm{a}$ & 7.0 & \pm 0.2 & $\mathrm{a}$ & - & - & \\
\hline & F5 & 1.14 & \pm 0.03 & $\mathrm{a}$ & 7.2 & \pm 0.2 & $\mathrm{a}$ & - & - & \\
\hline & F15 & 1.09 & \pm 0.14 & $\mathrm{a}$ & 7.1 & \pm 0.1 & $\mathrm{a}$ & - & - & \\
\hline & Rice & 1.11 & \pm 0.05 & $\mathrm{a}$ & 7.1 & \pm 0.2 & $\mathrm{a}$ & - & - & \\
\hline \multirow[t]{5}{*}{$20-30 \mathrm{~cm}$} & NT & 1.14 & \pm 0.05 & $\mathrm{a}$ & 7.1 & \pm 0.0 & $\mathrm{a}$ & - & - & \\
\hline & $\mathrm{NF}$ & 1.13 & \pm 0.06 & $\mathrm{a}$ & 6.9 & \pm 0.1 & $\mathrm{a}$ & - & - & \\
\hline & F5 & 1.06 & \pm 0.05 & $\mathrm{a}$ & 6.9 & \pm 0.2 & $\mathrm{a}$ & - & - & \\
\hline & F15 & 1.16 & \pm 0.03 & $\mathrm{a}$ & 7.0 & \pm 0.4 & $\mathrm{a}$ & - & - & \\
\hline & Rice & 1.10 & \pm 0.05 & $\mathrm{a}$ & 7.0 & \pm 0.2 & $\mathrm{a}$ & - & - & \\
\hline
\end{tabular}

Different letters indicate a significant difference between management practices at $P<0.05$. 
The soil $\mathrm{C}$ content in the top $10 \mathrm{~cm}$ was significantly higher in F5 (5.1 $\left.\mathrm{Mg} \mathrm{C} \mathrm{ha}^{-1}\right)$ than in NF (4.1 $\mathrm{Mg} \mathrm{C} \mathrm{ha}^{-1}$ ), but none of the other values were significantly different from one another (Fig. 3). The soil C contents in the unflooded fields (NT and NF) were lower than those of flooded fields (F5 and F15) at depths of 10-20 cm and 20-30 cm, although the differences were not significant. The soil $\mathrm{C}$ contents in all soil samples tended to decrease with depth. The soil $\mathrm{C}$ content to a depth of $30 \mathrm{~cm}$ was less in unflooded fields than it was in flooded fields (Fig. 3).

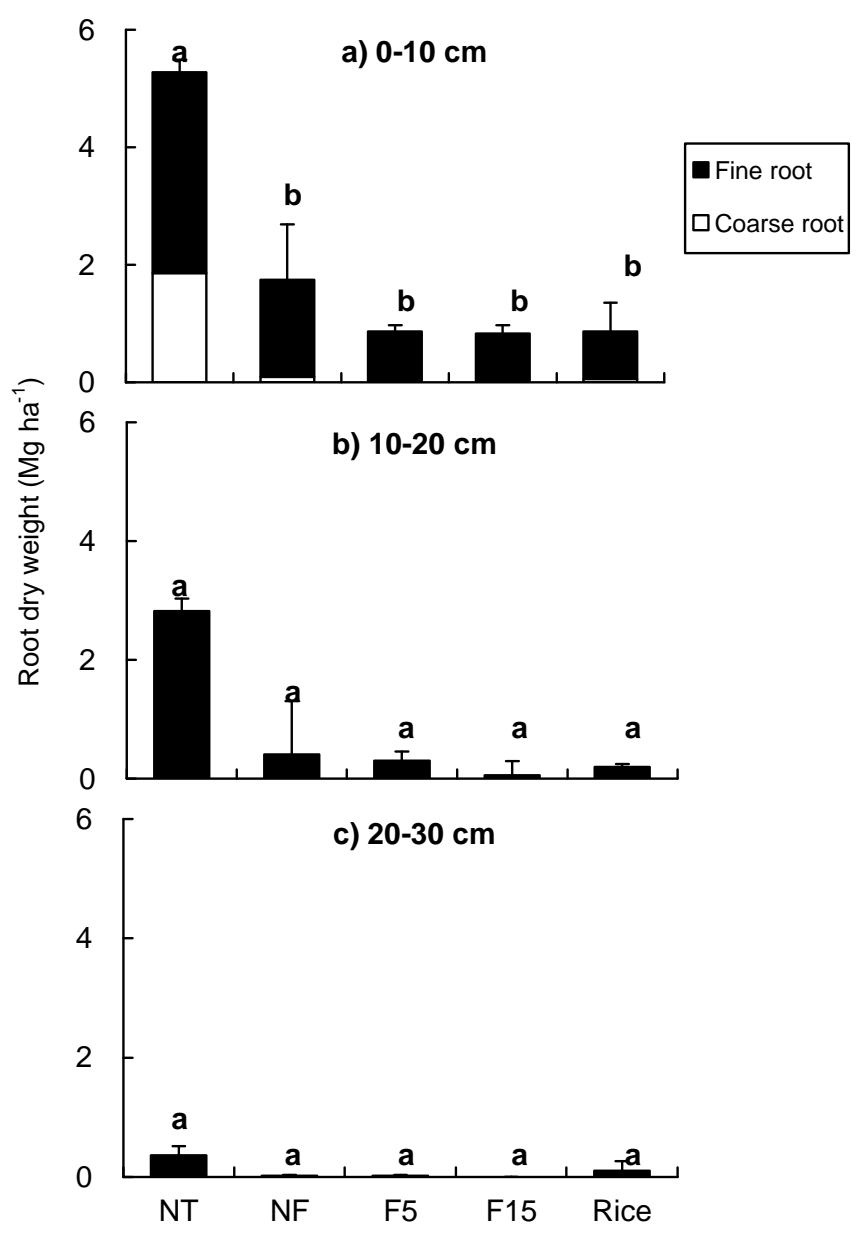

Figure 2. Root biomass to $30 \mathrm{~cm}$ in depth: (a) 0-10 cm, (b), 10-20 cm, and (c) 20-30 cm. Small bars indicate standard error. Different letters indicate a significant difference between management practices at $P<0.05$

The soil $\mathrm{N}$ content in the top $10 \mathrm{~cm}$ was significantly higher in NT $\left(0.40 \mathrm{Mg} \mathrm{N} \mathrm{ha}^{-1}\right)$ and F5 (0.39 $\mathrm{Mg} \mathrm{N} \mathrm{ha}^{-1}$ ) than in the other fields (Fig. 4). However, there was no significant difference in total soil $\mathrm{N}$ content to a depth of $30 \mathrm{~cm}$ among the fields (Fig. 4).

Soil $\delta^{13} \mathrm{C}$ in the top $10 \mathrm{~cm}$ was significantly lower in the rice field $(-26.7 \%$ o $)$ than in the other fields (Fig. 5a), and the value in NF was $3.5 \%$ higher than that of the rice field. The values in the top $10 \mathrm{~cm}$ decreased in the order of NF $>$ F5 $>$ F15 $>$ NT $>$ Rice, and the values at 10-20 cm showed a similar trend (Fig. 5b). In contrast, there were no significant differences among the 5 fields at $20-30 \mathrm{~cm}$ (Fig. 5c). The soil $\delta^{13} \mathrm{C}$ values in 
the 20-30-cm layer were greater than $-23.7 \%$ in each field, which was higher than they were in the shallower layers. This is because enrichment $\left(1 \%\right.$ - $2 \%$ of $\delta^{13} \mathrm{C}$ occurs in the advanced stages of soil organic matter decomposition and at greater depths in the soil horizon during the phase of decomposition of plant litter to soil organic matter (Melillo et al., 1989). The values of $f_{\mathrm{C}_{4}}$ show the relative contribution of weed-derived $\mathrm{C}$ to soil $\mathrm{C}$ in $\mathrm{NF}$ and $\mathrm{F} 5$ at $\mathrm{C}_{4}$-dominated fallow fields (Table 3). The values of $f_{\mathrm{C}_{4}}$ in $\mathrm{NF}$ and $\mathrm{F} 5$ were $26.0 \%$ and $20.9 \%$ in the top $10 \mathrm{~cm}$, and less than $5 \%$ in the $20-30-\mathrm{cm}$ layer (Table 3).

Table 3. The fraction of C4-derived $C\left(f_{C 4}\right)$ on the soil (\%) at each depth

\begin{tabular}{c|c|c}
\hline \multirow{2}{*}{ Depth(cm) } & \multicolumn{2}{|c}{ Treatment } \\
\cline { 2 - 3 } & NF & F5 \\
\hline $0-10$ & 26.0 & 20.9 \\
$10-20$ & 17.7 & 14.9 \\
$20-30$ & 1.9 & 4.8 \\
\hline
\end{tabular}

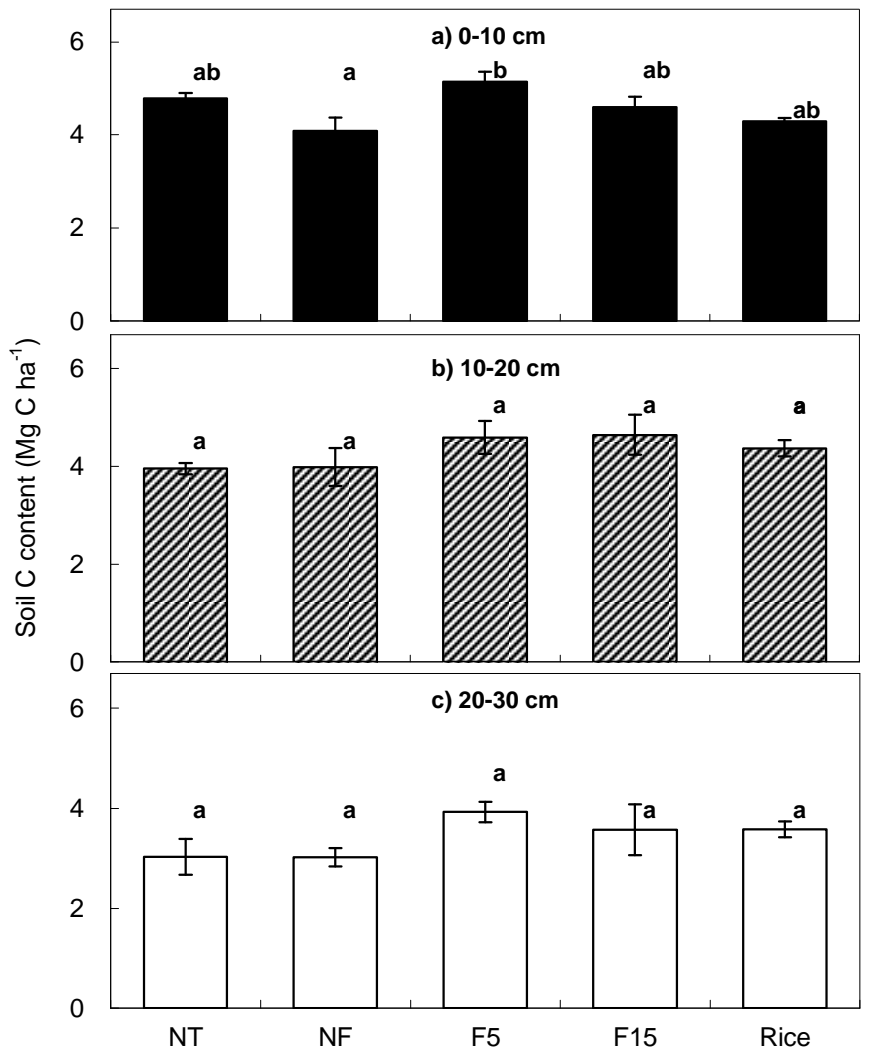

Figure 3. Soil C content $\left(\mathrm{Mg} \mathrm{ha}^{-1}\right)$ at each depth ( \pm standard error). Different letters indicate a significant difference between management practices at $P<0.05$ 


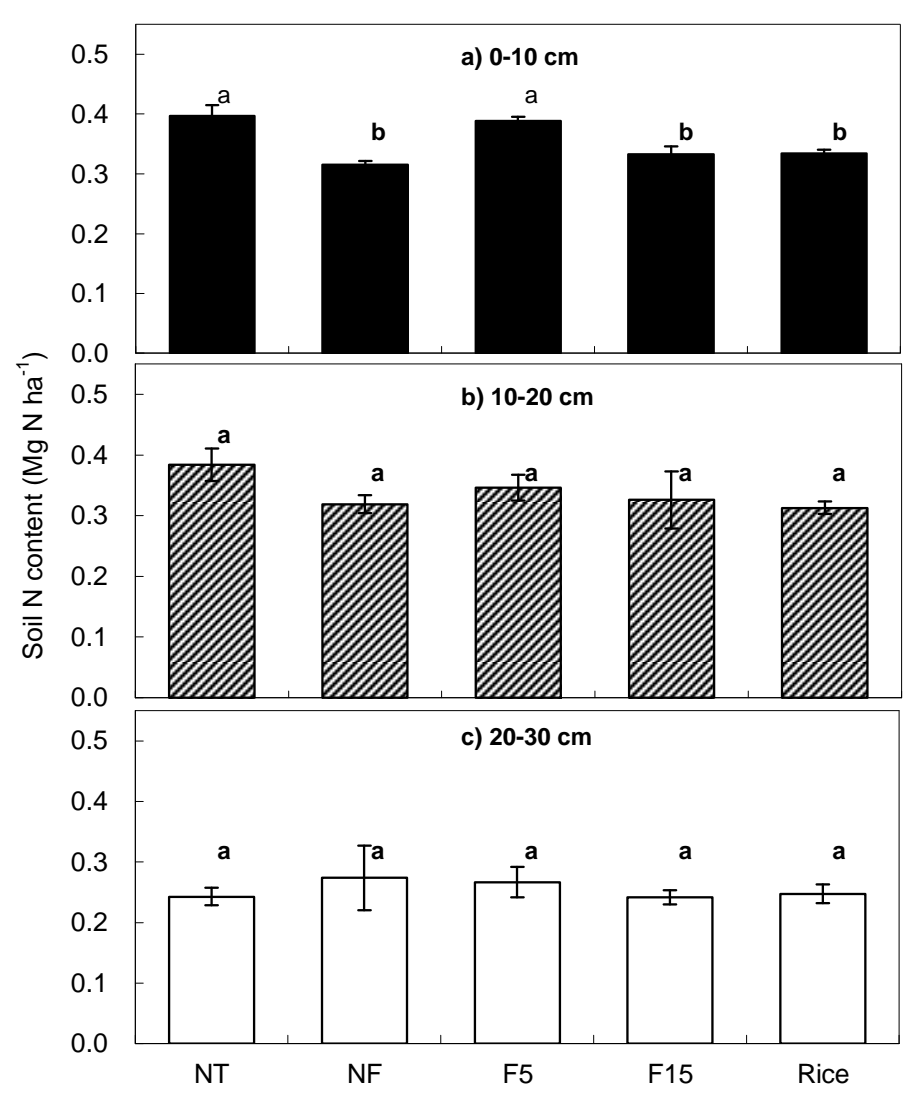

Figure 4. Soil $N$ content $\left(M g h a^{-1}\right)$ at each depth ( \pm standard error). Different letters indicate a significant difference between management practices at $P<0.05$

\section{Discussion}

If soil $\mathrm{C}$ is fortified with $\mathrm{C}_{4}$ plant litter, the soil $\delta^{13} \mathrm{C}$ value rises. The varied soil $\delta^{13} \mathrm{C}$ values in the top $10 \mathrm{~cm}$ among the fields reflected differences in the dominant vegetation: the $\mathrm{NF}$ and $\mathrm{F} 5$ fields had higher (less negative) soil $\delta^{13} \mathrm{C}$ values (Fig. 5a) on account of the dominance by upland weeds, including $\mathrm{C}_{4}$ D. ciliaris and E. oryzicola. In addition, the variation in the soil $\delta^{13} \mathrm{C}$ values in the $10-20-\mathrm{cm}$ layer coincided partly with the variation in vegetation type. The values of $f_{\mathrm{C}_{4}}$ in $\mathrm{NF}$ and $\mathrm{F} 5$ were decreased with depth (Table 3).

Carbon lost from the plant-soil system can be replenished by increased photosynthesis and production. Flooding management restricted the germination and growth of paddy weeds, whereas NT had the potential for a greater increase in soil C because of the larger root buildup (Fig. 2). The soil $\mathrm{C}$ content in the top $10 \mathrm{~cm}$, however, was similar in both NT $\left(4.8 \mathrm{Mg} \mathrm{C} \mathrm{ha}^{-1}\right)$ and F5 (5.1 $\left.\mathrm{Mg} \mathrm{C} \mathrm{ha}^{-1}\right)$. Komatsuzaki and Ohta (2007) showed that soil $\mathrm{C}$ storage in no-tiled upland accumulates extremely in near the soil surface. Although NT has the potential to increase soil C more than F5 because of the larger amount of plant residue, surface litter $\mathrm{C}$ would not return to the soil for at least 6 years after agricultural cessation. Root quality is another reason for reduced soil $\mathrm{C}$ in the NT field. Annual puddling restricts the dominance of rhizomatous perennials (Yamada et al., 2007), and our results show that a perennial species dominated only in the no-tilled field (NT; Table 1) and that coarse roots were also found almost exclusively in the untilled field. Fine roots act as conduits transporting $\mathrm{C}$ into 
belowground $\mathrm{C}$ pools, where the roots acquire soil resources. As the diameter of the root increases, root turnover decreases (e.g., Gill and Jackson, 2000). The percentage of fine root weight in the top $10 \mathrm{~cm}$ was the smallest in NT (Fig. 2), and this distribution may have contributed to the lower soil $\mathrm{C}$ values in NT than in F5. These results indicate that no-till management actually decreases soil $\mathrm{C}$ despite the greater root and shoot $\mathrm{C}$ input.

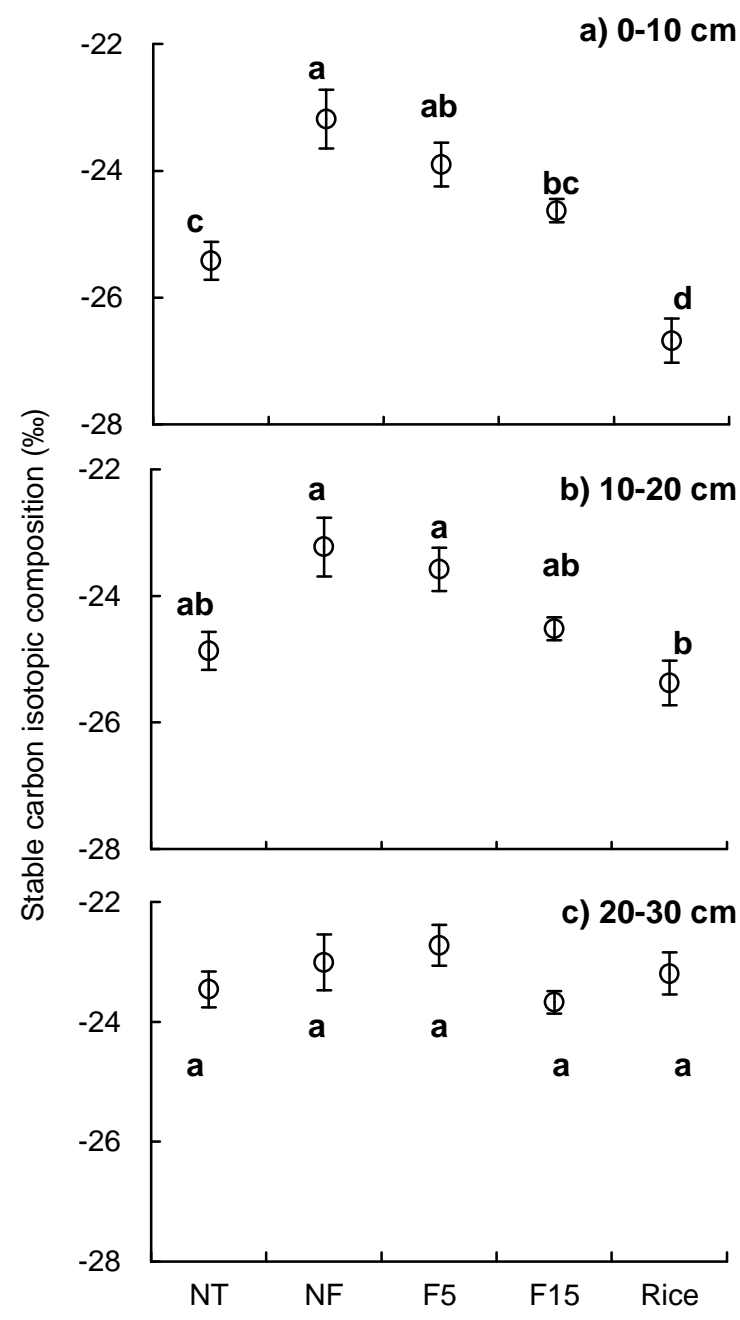

Figure 5. Mean soil stable carbon isotopic composition at each depth. (a) $0-10 \mathrm{~cm}$, (b) 10-20 $\mathrm{cm}$, and (c) 20-30 cm. Small bars indicate standard error. Different letters indicate a significant difference between management practices at $P<0.05$

These results indicate no-till management actually decreases soil $\mathrm{C}$ despite the greater root and shoot $\mathrm{C}$ input. In fact, the soil $\mathrm{C}$ contents in the top $30 \mathrm{~cm}$ in unflooded fields were significant lower than those in flooded fields at similar or greater root and shoot $\mathrm{C}$ input (Fig. 3). These results indicated that dry-fallow management increased plant growth while reducing soil C. A possibility is that anaerobic conditions delay soil organic $\mathrm{C}$ decomposition and result in a higher humication coefficient (remaining organic C) under flooding (Mitsuchi, 1974). Soil C would have more rapidly decomposed in unflooded fields than in flooded fields (with similar plant $\mathrm{C}$ input), 
which would lead to lower soil $\mathrm{C}$ in the unflooded fields. Some studies have suggested that cessation of agriculture increases soil $\mathrm{C}$ at poorly drained sites (e.g., Anzai and Matsumoto, 1988; Ohta et al., 1996; Zhang et al., 2007). In contrast, soil C decreased at well-drained sites after agriculture cessation in terraced paddies, where the wall of the bund is commonly dry and seepage is limited (Ohta et al., 1996; Shimoda, 2008). The soil $\mathrm{C}$ content was somewhat lower in the unflooded fields (NF and NT) than in the flooded fields at a depth of $20-30 \mathrm{~cm}$, but the difference was not significant. The soil $\mathrm{C}$ content of the rice field was in the mid range compared with those of the other treatments. Previous studies have tended to find larger $\mathrm{CO}_{2}$ emissions in intermittently flooded rice fields than in flooded rice fields (Miyata et al., 2000). The intermittently flooded management would not be helpful in restoring soil $\mathrm{C}$ content in rice fields.

The additional input from shoot $\mathrm{N}$ may have contributed to the higher soil $\mathrm{N}$ in the NT and F5 fields than in the other fields (Fig. 4). Whereas warm-season plant contribute to $\mathrm{C}$ input by increased photosynthesis and production, cool-season legume $\mathrm{N}$ fixation and $\mathrm{C}$ input contribute to soil $\mathrm{C}$ and $\mathrm{N}$ and promotes warm-season plant growth in temperate grassland ecosystems (Fornara and Tilman, 2008). Fallow paddy soils have the capacity to act as a significant sink for $\mathrm{CO}_{2}$, if appropriate changes in management practices are implemented.

Our results show that flooding management of fallow paddy fields can be an effective and cost-effective means of restoring soil $\mathrm{C}$, preventing succession to wasteland, and preparing for re-establishing of cultivation. Further study should focus on the assessment of the long-term effects of surface $\mathrm{C}$ accumulation and decomposition in the absence of flooding.

Acknowledgements. This study was supported by the project "Elucidation of Vulnerability of Agriculture, Forestry and Fishery to Global Warming and Development of Mitigation Techniques" of the Ministry of Agriculture, Forestry, and Fisheries of Japan. We thank Mutsuko Iwahara (Wenarc, Japan) for their experimental assistance. We also thank Dr Seiko Yoshikawa (National Institute for AgroEnvironmental Sciences, Japan) for valuable comments on this manuscript.

\section{REFERENCES}

[1] Anzai, T., Matsumoto, N. (1988): Emergence of weeds and changes in soil properties in fallow paddy fields. - Bulletin of the Chiba-Ken Agricultural Experiment Station 29: 93104 (in Japanese with English summary).

[2] Bhagat, R.M., Bhuiyan, S.I., Moody, K. (1996): Water, tillage and weed interactions in lowland tropical rice: a review. - Agricultural Water Management 31: 165-184.

[3] Bhagat, R.M., Bhuiyan, S.I., Moody, K., Estorninos, L.E. (1999): Effect of water, tillage and herbicide on ecology of weed communities in intensive wet-seeded rice system. Crop Protection 18: 293-303.

[4] Fornara, D.A., Tilman, D. (2008): Plant functional composition influences rates of soil carbon and nitrogen accumulation. - Journal of Ecology 96: 314-322.

[5] Gill, R.A., Jackson, R.B. (2000): Global patterns of root turnover for terrestrial ecosystems. - New Phytologist 147: 13-31.

[6] Kennedy, R.A., Barrett, S.C.H, Zee, D.V., Rumpho, M.E. (1980): Germination and seedling growth under anaerobic conditions in Echinochloa crus-galli (barnyard grass). Plant, Cell \& Environment. 3: 243-248. 
[7] Kent, R., Johnson, D.E., Becker, M. (2001): TThe influences of cropping system on weed communities of rice in Côte d'Ivoire, West Africa. - Agriculture, Ecosystems \& Environment 87: 299-307.

[8] Komatsuzaki, M. Ohta, H. (2007): Soil management practices for sustainable agroecosystems. - Sustainability Science 2: 103-120.

[9] MAFF (Ministry of Agriculture, Forestry and Fisheries of Japan) (2009): Annual Report on Food. - Agriculture and Rural Areas in Japan FY 2008. Tokyo: MAFF.

[10] Melillo, J.M., Aber, J.D., Linkins, A.E., Ricca, A., Fry, B., Nadelhoffer, K.J. (1989): Carbon and nitrogen dynamics along the decay continuum: plant litter to soil organic matter. - Plant and Soil 115: 189-198.

[11] Mitsuchi, M. (1974): Characters of humus formed under rice cultivation. Soil Science and Plant Nutrition 20: 249-259.

[12] Miyata, A., Leuning, R., Denmead, O.T., Kim, J., Harazono, Y. (2000): Carbon dioxide and methane fluxes from an intermittently flooded paddy field. - Agricultural and Forest Meteorology 102: 287-303.

[13] Mo, W., Nishimura, N., Soga, Y., Yamada, K., Yoneyama, T. (2004): Distribution of $C_{3}$ and $\mathrm{C}_{4}$ plants and changes in plant and soil carbon isotope ratios with altitude in the Kirigamine grassland, Japan. - Grassland Science 50: 243-254.

[14] Nishimura, S., Yonemura, S., Sawamoto, T., Shirato, Y., Akiyama, H., Sudo, S., Yagi, K. (2008): Effect of land use change from paddy rice cultivation to upland crop cultivation on soil carbon budget of a cropland in Japan. - Agriculture, Ecosystems \& Environment 125: 9-20.

[15] Ohta, K., Taniyama, I., Kusaba, T., Mori, A., Araya, H. (1996): Changes in the soil properties of terrace paddy fields with the years after abandoned. - Soil physical conditions and plant growth, Japan 73: 3-10 (in Japanese with English summary).

[16] Pan, G.X., Li, L.Q., Wu, L.S., Zhang, X.H. (2004): Storage and sequestration potential of organic carbon in China's paddy soils. - Global Change Biology 10: 79-92.

[17] Roumet, C., Urcelay, C., Diaz, S. (2006): Suites of root traits differ between annual and perennial species growing in the field. - New Phytologist 170: 357-368.

[18] Shimoda, M., Nakamoto, N. (2003): Vegetation and threatened plant dynamics of wet abandoned rice fields in Nakaikemi, Fukui Prefecture, Japan. - Japanese Journal of Ecology 53: 197-217 (in Japanese with English summary).

[19] Shimoda, S. (2008): Soil carbon content and stable isotope ratio in abandoned agricultural fields: land use change from paddy to upland grass in Higashi-Hiroshima, Japan. Journal of Agricultural Meteorology 64: 289-293.

[20] Shimoda, S., Murayama, S., Mo, W., Oikawa, T. (2009): Seasonal contribution of $C_{3}$ and $\mathrm{C}_{4}$ species to ecosystem respiration and photosynthesis estimated from isotopic measurements of atmospheric $\mathrm{CO}_{2}$ at a grassland in Japan. - Agricultural and Forest Meteorology 149: 603-613.

[21] Strassmann, K.M., Joos, F., Fischer, G. (2008): Simulating effects of land use changes on carbon fluxes: past contributions to atmospheric $\mathrm{CO}_{2}$ increases and future commitments due to losses of terrestrial sink capacity. - Tellus B 60:583- 603, doi:10.1111/j.16000889.2008.00340.x.

[22] Yamada, S., Okubo, S., Kitagawa, Y., Takeuchi, K. (2007): Restoration of weed communities in abandoned rice paddy fields in the Tama Hills, central Japan. Agriculture, Ecosystems \& Environment 119: 88-102.

[23] Yano, K., Sakurai, Y. (2009): Weeds control by the deeper irrigation in fallow paddy fields under various conditions. - Journal of Rainwater Catchment Systems 14: 59-65 (in Japanese with English summary).

[24] Zhang, J.B., Song, C.C., Wang, S.N. (2007): Dynamics of soil organic carbon and its fractions after abandonment of cultivated wetlands in northeast China. - Soil and Tillage Research 96: 350-360. 